\title{
A comparison of liveweight gain of lambs weaned early onto a herb-clover mixed sward and weaned conventionally onto a ryegrass-clover pasture and herb-clover mixed sward
}

\author{
W. E. M. L. J. Ekanayake ${ }^{1, *}$, R. A. Corner-Thomas ${ }^{1}$, L. M. Cranston ${ }^{1}$, P. R. Kenyon ${ }^{1}$, and S. T. Morris ${ }^{1}$
}

\begin{abstract}
* Corresponding Author: W. E. M. L. J. Ekanayake Tel: +64-21-023-312-35, Fax: +64-06-350-5636, E-mail: jayampathiekn@gmail.com
\end{abstract}

'Sheep Research Centre, School of Agriculture and Environment, Private Bag 11-222, Massey University, Palmerston North, 4442, New Zealand

ORCID

W. E. M. L. J. Ekanayake

https://orcid.org/0000-0003-3382-2548

Submitted Apr 16, 2018; Revised May 16, 2018; Accepted Jun 14, 2018
Objective: The aim of the present study was to identify the impact of early weaning of lambs at approximately seven weeks of age onto a herb-clover mix on the liveweight gain of lambs and their dams.

Methods: In 2015, twin-born lambs that weighed a minimum of $16 \mathrm{~kg}(\mathrm{n}=134)$ were randomly allocated to one of three treatments: i) Early-weaned (58 days after the midpoint of lambing) onto an unrestricted allowance $(>1,200 \mathrm{~kg}$ dry matter/ha) of herb-clover mix (HerbEW); ii) Lambs+dams unweaned onto an unrestricted allowance of herb-clover mix until conventional weaning (95 days after the midpoint of lambing) (HerbCW); iii) Lambs+ dams unweaned onto an unrestricted allowance of grass-clover pasture until conventional weaning (GrassCW). In 2016, twin-born lambs that weighed a minimum of $16 \mathrm{~kg}(\mathrm{n}=170)$ were randomly allocated to one of four treatments: i), ii), iii) (similar to 2015) and iv) Lambs+ dams unweaned onto a restricted allowance $(<1,200 \mathrm{~kg}$ dry matter/ha) of grass-clover pasture until conventional weaning (93 days after the midpoint of lambing) (Restricted-GrassCW). Results: In 2015, liveweight gain from L58 to L95 of HerbCW and GrassCW lambs did not differ ( $p>0.05$ ), but were greater than HerbEW lambs. In 2016, HerbCW lambs had greater $(p<0.05)$ liveweight gains from L51 to L93 than GrassCW followed by HerbEW and RestrictedGrassCW lambs. In 2015, liveweight gain from L58 to L95 of HerbEW ewes were greater than both GrassCW and HerbCW ewes while in 2016, liveweight gain of from L51 to L93 GrassCW and HerbCW ewes did not differ $(p>0.05)$ but were greater $(p<0.05)$ than those of HerbEW and Restricted-GrassCW ewes.

Conclusion: These results indicate that when grass-clover pasture supply can be maintained at unrestricted intake level, there may be no benefit of weaning lambs early. However, at restricted pasture conditions lambs can achieve greater liveweight gains when weaned early onto a herb-clover mix.

Keywords: Early Weaning; Growth; Herb; Lamb; Pasture Shortage

\section{INTRODUCTION}

A herb-clover mix containing plantain (Plantago lanceolata), chicory (Cichorium intybus), red clover (Trifolium pretense), and white clover (Trifolium repens) has been shown to produce greater herbage yields than a predominant perennial ryegrass-white clover pasture in New Zealand [1,2]. Further, the herb-clover mix has higher quality and digestibility than perennial ryegrass-white clover pasture [1,3-5]. These traits of herb-clover mix have resulted in improved ewe performance (liveweight gain, body condition, milk production; [6,7] and pre- and post-weaning lamb growth $[1,8,9]$ compared to a grass-clover pasture.

In lamb production systems in New Zealand, lambs are conventionally weaned between 10 and 14 weeks of age onto grass-clover pastures [10]. Under this system, and especially 
during seasons where there is a shortage of grass-clover pasture, the ewe and lamb can become competitors for the same feed resource [11]. As a result, the liveweight gain of lambs prior to conventional weaning can be disappointing. In New Zealand, the production of grass-clover pasture can be limited in late-spring and early-summer $[12,13]$. Therefore, offering ad-libitum feeding conditions ( $>1,200 \mathrm{~kg}$ dry matter [DM]/ha; $[3,14]$ ) can be a challenge for sheep farmers. Early weaning onto high quality herbages such a herb-clover mix during such conditions is a potential option to reduce overall feed demand, and allow both lambs and ewes to achieve higher liveweight gains $[5,11]$. To date no studies have examined the use of a herb-clover mix for early weaned lambs. Therefore, the aim of the present study was to identify the impact of early weaning of lambs at approximately seven weeks of age onto a herbclover mix on the liveweight gain of lambs and their dams. Over a two-year period, unrestricted and restricted pasture conditions were utilized. It was hypothesised that a positive effect for both ewe and her lamb was more likely to occur from early weaning when pasture availability was low.

\section{MATERIALS AND METHODS}

\section{Experimental design}

This study was conducted at Massey University's Tuapaka farm $15 \mathrm{~km}$ east of Palmerston North, New Zealand (latitude $40^{\circ} 20^{\prime} \mathrm{S}$, longitude $175^{\circ} 43^{\prime} \mathrm{E}$ ). All manipulations were approved by the Massey University Animal Ethics Committee. Romney ewes ( $n=65$ in 2015 and $n=83$ in 2016) which conceived during a 17-day breeding period and that were diagnosed bearing twin fetuses using transabdominal ultrasound were enrolled in the study. Throughout the gestation period, within each year, ewes were managed as one mob under commercial farming conditions. Lambing began on 02 September in 2015 and 31 August in 2016. All lambs were weighed, ear tagged and identified to their dam within $24 \mathrm{~h}$ of birth.

From the midpoint of lambing (L1) until the onset of the study (L58 and L51 in 2015 and 2016, respectively), lambs and ewes were managed as a single mob on a ryegrass dominant clover pasture. Lambs were orally drenched every 28 days, as per standard practice in New Zealand, beginning at L26 in 2015 and L25 in 2016 with Ancare 'Matrix' triple combination drench (Merial Ancare, Manukau City, New Zealand) at a rate of $1 \mathrm{~mL}$ per $5 \mathrm{~kg}$ live weight to reduce the risk of worm burden. Ewes that successfully reared both lambs to minimum of $16 \mathrm{~kg}$ were subsequently enrolled in the study and allocated to one of three weaning treatments at L58 in 2015 and four weaning treatments at L51 in 2016 (Table 1). Two grass-clover pasture herbages were used in 2016 to allow for comparison of the impact of early weaning onto herb-clover mix when pasture conditions were either restricted or unrestricted. In 2015, ewes weaned early onto a herb-clover mix (HerbEW) were managed with unweaned ewes and lambs on grass-clover pasture at unrestricted allowance (GrassCW) until conventional weaning. In 2016, ewes in HerbEW treatment were managed with unweaned ewes and lambs on grass-clover pasture at restricted allowance (Restricted-GrassCW) until conventional weaning. Early weaned lambs on the herb-clover mix were managed with unweaned ewes and lambs in both years. Within 1 to 2 $h$ of birth, ewes develop an exclusive bond with their lambs and reject any alien lambs that attempt to suck for the remainder of the lactation [15]. Therefore, it is unlikely that weaned lambs were stealing milk from unweaned ewes.

Three paddocks of herb-clover mix (7.8 ha in total land area) and three paddocks of grass-clover pasture (5.2 ha in total land area) were used for the duration of the study. Lambs and ewes allocated to treatments at L58 in 2015 and L51 in 2016 were rotationally grazed. During the experimental peri-

Table 1. Summary of the experimental design including the number of lambs allocated to each weaning treatments

\begin{tabular}{|c|c|c|}
\hline Weaning treatment $^{1)}$ & Number of lambs & Treatment description \\
\hline \multicolumn{3}{|l|}{2015} \\
\hline HerbEW ${ }^{A}$ & 44 & $\begin{array}{l}\text { Early weaning at } 58 \text { after the mid-point if lambing (L58) with unrestricted allowance of herb-clover mix (plantain } \\
\text { red clover and white clover) until conventional weaning at L95 }\end{array}$ \\
\hline $\mathrm{HerbCW}^{\mathrm{B}}$ & 42 & Lambs+dams offered an unrestricted allowance of herb-clover mix until conventional weaning at L95 \\
\hline GrassCW & 44 & $\begin{array}{l}\text { Lambs+dams offered unrestricted allowance of grass-clover pasture (Ryegrass, red clover and white clover) until } \\
\text { conventional weaning at L95 }\end{array}$ \\
\hline \multicolumn{3}{|l|}{2016} \\
\hline HerbEW & 44 & Early weaning at L51with unrestricted allowance of herb-clover mix until conventional weaning at L93 \\
\hline $\mathrm{HerbCW}^{\mathrm{E}}$ & 42 & Lambs+dams offered an unrestricted allowance of herb-clover mix until conventional weaning at L93 \\
\hline GrassCW ${ }^{F}$ & 38 & Lambs+dams offered unrestricted allowance of grass-clover pasture until conventional weaning at L93 \\
\hline Restricted-GrassCW ${ }^{G}$ & 40 & Lambs+dams offered with restricted allowance of grass-clover pasture until conventional weaning at L93 \\
\hline
\end{tabular}


od, pastures were managed to provide ad-libitum intakes $(>1,200 \mathrm{~kg} \mathrm{DM} / \mathrm{ha})$ except in the GrassCW treatment in 2016 which was managed to maintain masses below 1,200 $\mathrm{kg} \mathrm{DM} /$ ha to provide restricted supply of pasture. Ewes and lambs remained on their respective herbages until conventional weaning (at 95 and 93 days from midpoint of lambing in 2015 and 2016, respectively). Lambs and ewes assigned to the HerbEW and HerbCW (Lambs+dams unweaned onto an unrestricted allowance of herb-clover mix until conventional weaning) treatments were gradually introduced to herbclover mix over a four-day period from L55 in 2015 and from L48 in 2016) of increasing duration on each day (i.e. $4 \mathrm{~h}$ day $1,8 \mathrm{~h}$ day $2,12 \mathrm{~h}$ day 3 , and $24 \mathrm{~h}$ day 4 ) prior to the onset of the main study. Lambs and ewes were weighed within $1 \mathrm{~h}$ of being bought off their herbages on L58, L81 and L95 in 2015 and L51, L82 and L93 in 2016. Post-grazing sward surface heights were maintained by grazing down to a minimum of five $\mathrm{cm}$ in the grass-clover pasture and seven $\mathrm{cm}$ in the herbclover mix to provide unrestricted access to herbage. In the Restricted-GrassCW treatment group pasture was maintained below five $\mathrm{cm}$ to restrict intakes. In 2015, $\mathrm{n}=1$ and $\mathrm{n}=2$ lambs either lost their tag or died in HerbCW and GrassCW treatments, respectively. In 2016, $\mathrm{n}=2, \mathrm{n}=4, \mathrm{n}=3$, and $\mathrm{n}=1$ lambs either lost their tag or died in HerbEW, HerbCW, GrassCW, and Restricted-GrassCW treatments, respectively. No ewes died in 2015. In 2016, one ewe either lost her tag or died in HerbEW treatment.

\section{Herbage measurements}

Herbage masses were measured on L58, L81, and L95 in 2015 and, L51, L69, and L82 in 2016. Four random quadrat cuts $\left(0.1 \mathrm{~m}^{2}\right.$ each) were taken to ground level from each herbage at each sampling date using an electric shearing hand-piece [16] and samples were oven dried $\left(60^{\circ} \mathrm{C}\right.$ to $\left.70^{\circ} \mathrm{C}\right)$ to a constant weight to estimate herbage mass. In addition, four grab samples per herbage were also collected at each sampling date to estimate the botanical composition and nutritional composition of each herbage [16]. A subsample from each sample was sorted into sown species (Ryegrass, red clover and white clover for grass-clover pasture and plantain red clover and white clover for herb-clover mix), weeds and dead matter, and then oven dried and weighed to attain the botanical composition. The remaining sample was then freeze dried, ground, sieved (one $\mathrm{mm}$ ) and analysed using in vitro methods to determine the nutritional quality; dry matter digestibility (DMD [17]) and crude protein (CP; Dumas' procedure, AOAC method 968.06 using a Leco total combustion method, LECO Corporation, St. Joseph, MI, USA [18]). Acid detergent fibre (ADF) was analysed by a Tecator Fibretec System [19]. Metabolisable energy content of roughages was calculated using the organic matter digestibility [17].

\section{Statistical analysis}

Live weight and liveweight gain of lambs were subjected to analysis of variance using the MIXED procedure in SAS (Statistical Analysis System, version 9.2; SAS Institute Inc., Cary, NC, USA). The analysis was performed separately for each year due to the differences in the days on which measurements were collected. The effect of treatment on the liveweight gain of lambs and ewes were analysed using individual animal within year as the experimental unit allowing for repeated measures. The effect of weaning treatment on lamb live weight and liveweight gain were analysed using a model that included the fixed effects of weaning treatment and sex of lamb. The exact age of lambs at the start of the treatments was included in the model as a covariate but was found not to be significant ( $>0.05$ ), and therefore it was not included in the model. Ewe live weights were analysed in a model including the fixed effects of measurement time, weaning treatment and the interaction between measurement time and weaning treatment. Ewe body condition score was analysed using the GENMOD procedure in SAS that included the fixed effects of weaning treatment.

Botanical composition data were analysed using the MIXED procedure, with a model including the fixed effects of plant species and measurement time. The herbage quality data were analysed using the MIXED procedure, with a model including the fixed effects of pasture type and measurement time. The means were separated using least significant difference $(L S D)$ procedure $(\mathrm{p}<0.05)$ in proc general linear model. Herbage masses were analysed using a model that included weaning treatment and measurement times as fixed effects.

\section{RESULTS}

\section{Botanical composition, herbage mass and nutritional quality of herbage}

The mean percentage of plantain in herb-clover mix was $63.3 \%$ $\pm 5.6 \%$ and $36.5 \% \pm 7.7 \%$ in 2015 and 2016, respectively (Figure 1). Mean percentage of total clover in herb-clover mix was $16.4 \% \pm 3.3 \%$ in 2015 and $9.2 \% \pm 4.3 \%$ in 2016 . The remaining portion of the herb-clover mix was made up of grasses and weeds. In both years, ryegrass was the dominant species (77\% to $93 \%$ in 2015 and $64 \%$ to $87 \%$ in 2016 ) in the grass-clover pasture (Figure 1). The mean percentage of clover in grassclover pasture was $6.1 \% \pm 1.2 \%$ in 2015 and $1.0 \% \pm 0.2 \%$ in 2016 . The remaining portion of the grass-clover pasture was made up of weeds.

In 2015 the herbage mass of unrestricted herb-clover mix and grass-clover pasture were maintained at a minimum of $2,647 \pm 349$ and $1,352 \pm 349 \mathrm{~kg} \mathrm{DM} / \mathrm{ha}$, respectively. In 2016, the herbage mass was maintained at a minimum of $3,501 \pm 275$ for unrestricted herb-clover mix and $1,353 \pm 390 \mathrm{~kg} \mathrm{DM} /$ ha for grass-clover pasture. The minimum and maximum masses of restricted grass-clover pasture in 2016 were $799 \pm 390$ and 
A

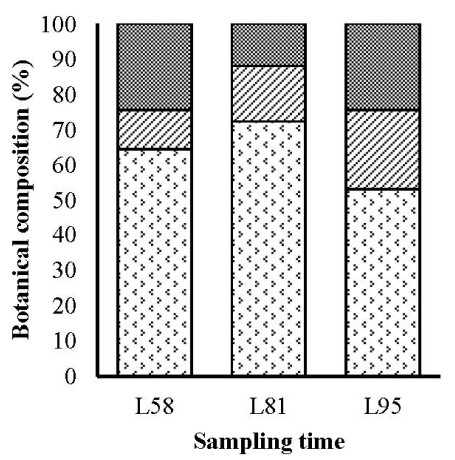

C

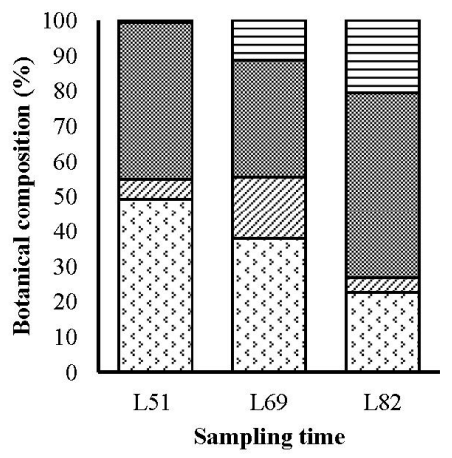

Grass+weed aClover 口Plantain

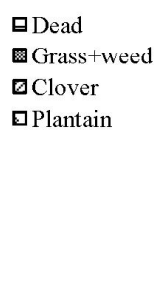

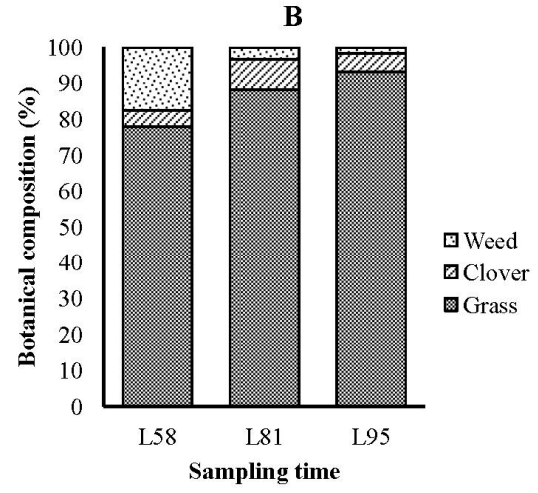

D

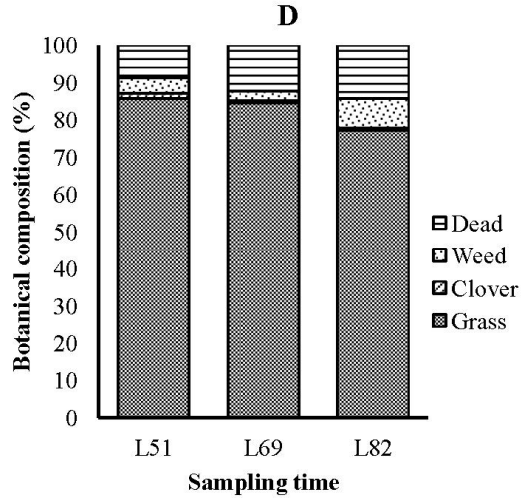

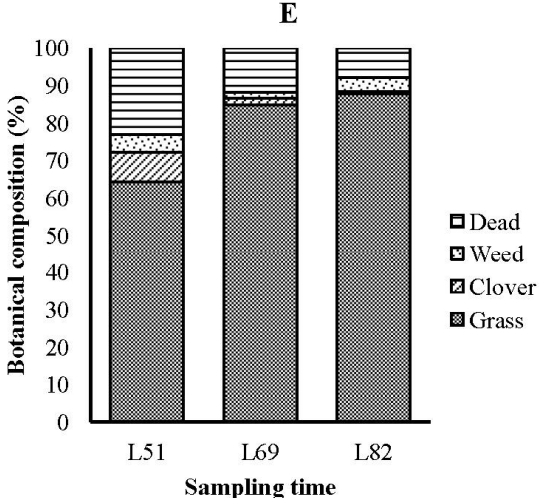

Figure 1. The botanical composition of herbages; herb-clover mix (A), grass-clover pasture (B) in 2015 and herb-clover mix (C), grass-clover pasture (D) and restrictedgrass-clover pasture (E) in 2016. L, days after the midpoint of lambing; on herbage A and C there were HerbEW lambs, HerbCW lambs, and their ewes. On herbage B there were GrassCW lambs and their ewes and HerbEW ewes. On herbage D there were GrassCW lambs and their ewes. On herbage E there were Restricted-GrassCW lambs and their ewes and HerbEW ewes. HerbEW, early weaning onto unrestricted allowance of herb-clover mix; HerbCW, lambs+dams offered an unrestricted allowance of herbclover mix until conventional weaning; Grass $\mathrm{CW}$, lambs+dams offered unrestricted allowance of grass-clover pasture until conventional weaning; Restricted-GrassCW, lambs+dams offered with restricted allowance of grass-clover pasture until conventional weaning.

$935 \pm 318 \mathrm{~kg} \mathrm{DM} / \mathrm{ha}$, respectively.

In 2015, the CP content of grass-clover pasture at the start of the study was greater $(\mathrm{p}<0.05)$ than that of herb-clover mix (Table 2). At L95, however the reverse was observed and no difference $(\mathrm{p}>0.05)$ was observed at L81. The ADF content of grass-clover pasture and herb-clover mix at L58 and L81 did not differ ( $p>0.05)$, but at L95 grass-clover pasture had a greater $(\mathrm{p}<0.05)$ ADF content than the herb-clover mix. DMD of herb-clover mix was greater $(\mathrm{p}<0.05)$ than that of grass-clover pasture at all three measurement times. The metabolisable energy (ME) content of grass-clover pasture was greater $(\mathrm{p}<$ 0.05 ) than herb-clover mix at L58 but reverse was observed at L81 and L95.

In 2016, at the start of the study the CP content of herbclover mix and restricted-grass-clover pasture did not differ $(\mathrm{p}>0.05)$ but was less $(\mathrm{p}<0.05)$ than that of grass-clover pasture (Table 2). At L69 and L82, the CP content of restrictedgrass-clover pasture, grass-clover pasture and herb-clover mix differed $(\mathrm{p}<0.05)$. At L51, the ADF content of grass-clover pasture and herb-clover mix did not differ $(\mathrm{p}>0.05)$ but was less $(\mathrm{p}<0.05)$ than that of restricted-grass-clover pasture. At
L69, the ADF content of herb-clover mix did not differ ( $p>$ $0.05)$ from the ADF content of grass-clover pasture but was greater $(\mathrm{p}<0.05)$ than that of restricted-grass-clover pasture. At L82, the ADF content of herb-clover did not differ ( $p>0.05)$ from the $\mathrm{ADF}$ content of restricted-grass-clover pasture but was greater $(p<0.05)$ than grass-clover pasture. At L51, DMD of herb-clover mix was greater $(\mathrm{p}<0.05)$ than that of grassclover pasture which in turn was greater $(\mathrm{p}<0.05)$ than that of restricted-grass-clover pasture. At L69, DMD of herbage did not differ ( $p>0.05$ ) between the three treatments. At L82, DMD of grass-clover pasture and restricted-grass-clover pasture did not differ $(p>0.05)$ but was greater $(p<0.05)$ than that of herb-clover mix. At the start of the study (L51), the ME content of all treatments differed $(p>0.05)$. The ME content of herb-clover mix was greater $(\mathrm{p}<0.05)$ than that of grass-clover pasture followed by restricted-grass-clover pasture. At L69, the $\mathrm{ME}$ content of herb-clover mix and restricted-grass-clover pasture did not differ $(\mathrm{p}>0.05)$ but was greater $(\mathrm{p}<0.05)$ than grass-clover pasture. At the end of the study the ME did not differ $(p>0.05)$ between herbages. 
Table 2. Nutritional composition of herbages (least-squares mean \pm SEM)

\begin{tabular}{|c|c|c|c|c|c|}
\hline Herbage $^{1)}$ & & $\mathrm{CP}(\%)$ & ADF $(\%)$ & DMD (\%) & ME (MJ/kg) \\
\hline \multicolumn{6}{|l|}{2015} \\
\hline \multirow[t]{3}{*}{ Herb-clover mix ${ }^{A}$} & L58 & $15.9^{b} \pm 1.1$ & $19.9^{\mathrm{a}} \pm 1.1$ & $73.0^{e} \pm 0.5$ & $10.1^{c} \pm 0.1$ \\
\hline & L81 & $14.7^{b} \pm 1.1$ & $31.0^{c} \pm 1.1$ & $69.2^{c} \pm 0.5$ & $10.1^{\complement} \pm 0.1$ \\
\hline & L95 & $15.0^{b} \pm 1.1$ & $23.3^{b} \pm 1.1$ & $73.0^{e} \pm 0.5$ & $10.7^{\mathrm{e}} \pm 0.1$ \\
\hline \multirow[t]{3}{*}{ Grass-clover pasture $^{B}$} & L58 & $22.6^{c} \pm 1.1$ & $21.4^{\mathrm{ab}} \pm 1.1$ & $71.0^{d} \pm 0.5$ & $10.4^{d} \pm 0.1$ \\
\hline & L81 & $15.3^{b} \pm 1.1$ & $32.5^{c} \pm 1.1$ & $64.4^{b} \pm 0.5$ & $9.7^{b} \pm 0.1$ \\
\hline & L95 & $12.1^{\mathrm{a}} \pm 1.1$ & $35.0^{d} \pm 1.1$ & $59.5^{a} \pm 0.5$ & $8.9^{a} \pm 0.1$ \\
\hline \multicolumn{6}{|l|}{2016} \\
\hline \multirow[t]{3}{*}{ Herb-clover mix } & L51 & $16.4^{b} \pm 1.2$ & $25.5^{a} \pm 2.5$ & $70.0^{e} \pm 1.0$ & $10.2^{\mathrm{e}} \pm 0.3$ \\
\hline & L69 & $13.1^{\mathrm{a}} \pm 1.2$ & $37.6^{d} \pm 2.5$ & $63.3^{a b c} \pm 1.0$ & $9.1^{d} \pm 0.3$ \\
\hline & L82 & $12.8^{\mathrm{a}} \pm 1.2$ & $38.2^{d} \pm 2.5$ & $62.0^{\mathrm{a}} \pm 1.0$ & $8.5^{\mathrm{bcd}} \pm 0.3$ \\
\hline \multirow[t]{3}{*}{ Grass-clover pasture $^{D}$} & L51 & $20.2^{\text {cd }} \pm 1.2$ & $28.3^{\mathrm{ab}} \pm 2.5$ & $66.1^{d} \pm 1.0$ & $9.1^{d} \pm 0.3$ \\
\hline & L69 & $17.9^{b c} \pm 1.2$ & $35.6^{\text {cd }} \pm 2.5$ & $62.5^{\mathrm{ab}} \pm 1.0$ & $8.2^{\mathrm{ab}} \pm 0.3$ \\
\hline & L82 & $16.4^{b} \pm 1.2$ & $27.5^{\mathrm{ab}} \pm 2.5$ & $64.2^{b c d} \pm 1.0$ & $9.0^{\text {cd }} \pm 0.3$ \\
\hline \multirow[t]{3}{*}{ Restricted-Grass-clover pasture ${ }^{\mathrm{E}}$} & L51 & $16.4^{b} \pm 1.2$ & $34.7^{\text {cd }} \pm 2.9$ & $61.7^{a} \pm 1.0$ & $7.5^{\mathrm{a}} \pm 0.3$ \\
\hline & L69 & $20.6^{d} \pm 1.2$ & $31.0^{b c} \pm 2.5$ & $63.2^{\mathrm{abc}} \pm 1.0$ & $8.5^{\mathrm{bcd}} \pm 0.3$ \\
\hline & L82 & $19.6^{\mathrm{cd}} \pm 1.2$ & $38.3^{\mathrm{d}} \pm 2.5$ & $64.6^{\text {cd }} \pm 1.0$ & $8.2^{\mathrm{abc}} \pm 0.3$ \\
\hline
\end{tabular}

SEM, standard error of the mean; $C P$, crude protein; ADF, acid detergent fibre; DMD, dry matter digestibility; ME, metabolisable energy content; L, days after the midpoint of lambing.

1) On herbage $A$ and $C$ there were HerbEW lambs and HerbCW lambs and their ewes. On herbage B there were Grass CW lambs and their ewes and HerbEW ewes. On herbage $D$ there were Grass CW lambs and their ewes. On herbage $E$ there were Restricted-GrassCW lambs and their ewes and HerbEW ewes.

${ }^{a \cdot e}$ Means with different superscripts are significantly different within each year $(p<0.05)$.

\section{Lamb live weight and liveweight gain}

In 2015, the live weight of lambs at L81 and L95 in HerbCW and GrassCW treatment groups did not differ ( $\mathrm{p}>0.05)$ but were greater $(\mathrm{p}<0.05)$ than lambs in HerbEW (Table 3$)$. The liveweight gain of lambs between L58 and L95 in the HerbCW $(325 \pm 7 \mathrm{~g} / \mathrm{d})$ and GrassCW $(321 \pm 7 \mathrm{~g} / \mathrm{d})$ treatments did not differ $(p>0.05)$ but were greater $(p<0.05)$ than those of HerbEW lambs $(251 \pm 7 \mathrm{~g} / \mathrm{d})$.

In 2016, the live weight of lambs in HerbCW treatment group at L82 and L93 was greater $(\mathrm{p}<0.05)$ than lambs in HerbEW, GrassCW, and Restricted-GrassCW treatment groups
(Table 3). Live weight at L82 and L93 of HerbEW and GrassCW lambs did not differ $(p>0.05)$ but were greater $(p<0.05)$ than those of Restricted-GrassCW lambs. Lamb liveweight gains between L51 and L93 of HerbCW ( $307 \pm 8 \mathrm{~g} / \mathrm{d})$ lambs was greater $(\mathrm{p}<0.05)$ than those of GrassCW $(263 \pm 7 \mathrm{~g} / \mathrm{d})$, HerbEW $(240 \pm 7 \mathrm{~g} / \mathrm{d})$ and Restricted-GrassCW $(153 \pm 7 \mathrm{~g} / \mathrm{d})$ lambs.

\section{Ewe live weight, liveweight gain, and body condition score}

In 2015, at L58 the live weight of ewes in each treatment group

Table 3. Effect of weaning treatment on live weight of lambs (least-squares mean \pm SEM)

\begin{tabular}{|c|c|c|c|c|c|c|}
\hline Weaning treatment $^{1)}$ & $\mathbf{n}$ & Live weight $(\mathrm{kg})$ & $\mathbf{n}$ & Live weight $(\mathrm{kg})$ & $n$ & Live weight $(\mathrm{kg})$ \\
\hline 2015 & & L58 & & L81 & & L95 \\
\hline HerbEW ${ }^{A}$ & 44 & $22.5 \pm 0.3^{\mathrm{a}}$ & 43 & $27.8 \pm 0.3^{b}$ & 44 & $31.8 \pm 0.3^{d}$ \\
\hline HerbCW $^{B}$ & 42 & $22.5 \pm 0.3^{\mathrm{a}}$ & 42 & $29.8 \pm 0.3^{c}$ & 41 & $34.5 \pm 0.3^{\mathrm{e}}$ \\
\hline GrassCW & 44 & $22.7 \pm 0.3^{\mathrm{a}}$ & 42 & $30.0 \pm 0.3^{c}$ & 42 & $34.2 \pm 0.3^{e}$ \\
\hline 2016 & & $\mathrm{~L} 51$ & & L82 & & L93 \\
\hline HerbEW ${ }^{D}$ & 44 & $19.9 \pm 0.3^{\mathrm{a}}$ & 43 & $28.4 \pm 0.3^{d}$ & 42 & $30.0 \pm 0.3^{e}$ \\
\hline HerbCW $^{\mathrm{E}}$ & 42 & $20.0 \pm 0.3^{\mathrm{a}}$ & 39 & $30.5 \pm 0.3^{e}$ & 38 & $33.0 \pm 0.3^{f}$ \\
\hline GrassCW ${ }^{F}$ & 38 & $19.7 \pm 0.3^{\mathrm{a}}$ & 38 & $28.5 \pm 0.3^{d}$ & 35 & $30.8 \pm 0.3^{e}$ \\
\hline Restricted-GrassCW ${ }^{G}$ & 40 & $19.5 \pm 0.3^{\mathrm{a}}$ & 39 & $24.8 \pm 0.3^{b}$ & 39 & $25.8 \pm 0.3^{c}$ \\
\hline
\end{tabular}

SEM, standard error of the mean; $L$, days after the midpoint of lambing; HerbEW, early weaning onto unrestricted allowance of herb-clover mix; HerbCW, lambs+dams offered an unrestricted allowance of herb-clover mix until conventional weaning; Grass CW, lambs+dams offered unrestricted allowance of grass-clover pasture until conventional weaning; Restricted-GrassCW, lambs+dams offered with restricted allowance of grass-clover pasture until conventional weaning.

1) Lambs in A and D grazed with lambs and their ewes in B and E in 2015 and 2016, respectively. Lambs in B and E grazed with their ewes in B (2015) and E (2016). In 2015, lambs in C grazed with C ewes and A ewes. In 2016, F lambs grazed with their ewes in F. Lambs in G grazed with G ewes and D ewes.

${ }^{a-f}$ Means with different superscripts are significantly different within each year $(p<0.05)$. 
Table 4. Effect of weaning treatment on live weight of ewes (least-squares mean \pm SEM)

\begin{tabular}{|c|c|c|c|c|c|c|}
\hline Weaning treatment $^{1)}$ & $\mathrm{n}$ & Live weight (kg) & $\mathrm{n}$ & Live weight $(\mathrm{kg})$ & $\mathrm{n}$ & Live weight (kg) \\
\hline 2015 & & L58 & & L81 & & L95 \\
\hline HerbEW $^{A}$ & 22 & $72.0 \pm 1.8^{\mathrm{a}}$ & 21 & $77.1 \pm 1.8^{\mathrm{de}}$ & 22 & $79.8 \pm 1.8^{e}$ \\
\hline GrassCW ${ }^{c}$ & 22 & $70.6 \pm 1.7^{\mathrm{a}}$ & 22 & $73.7 \pm 1.7^{\mathrm{abcd}}$ & 22 & $75.9 \pm 1.7^{\mathrm{cd}}$ \\
\hline 2016 & & L51 & & L82 & & L93 \\
\hline HerbEW ${ }^{D}$ & 22 & $70.8 \pm 1.6^{b}$ & 22 & $68.8 \pm 1.6^{\mathrm{ab}}$ & 21 & $69.5 \pm 1.6^{a b}$ \\
\hline Restricted-GrassCW ${ }^{G}$ & 20 & $71.3 \pm 2.0^{b c}$ & 20 & $66.9 \pm 2.0^{\mathrm{a}}$ & 20 & $67.0 \pm 2.0^{a}$ \\
\hline
\end{tabular}

SEM, standard error of the mean; L, days after the midpoint of lambing; HerbEW, early weaning onto unrestricted allowance of herb-clover mix; HerbCW, lambs+dams offered an unrestricted allowance of herb-clover mix until conventional weaning; GrassCW, lambs+dams offered unrestricted allowance of grass-clover pasture until conventional weaning; Restricted-GrassCW, lambs+dams offered with restricted allowance of grass-clover pasture until conventional weaning.

${ }^{1)} A$ ewes grazed with $C$ lambs and their ewes in 2015. B and E ewes grazed with their lambs in B and $E$, respectively. $C$ ewes grazed with C lambs and A ewes in 2015. In 2016, D ewes grazed with $G$ ewes and their lambs. F ewes grazed with their lambs in $F$. $G$ ewes grazed with their lambs in $G$ and $D$ ewes.

${ }^{a-d}$ Means with different superscripts are significantly different within each year $(p<0.05)$.

did not differ ( $\mathrm{p}>0.05)$ (Table 4). At L81, live weight of ewes in HerbEW did not differ ( $\mathrm{p}>0.05)$ from ewes in GrassCW, but they were heavier $(\mathrm{p}<0.05)$ than HerbCW ewes. At L95, HerbEW ewes were heavier $(\mathrm{p}<0.05)$ than both HerbCW and GrassCW ewes. Liveweight gain between L58 and L95 of HerbEW ewes $(211 \pm 18 \mathrm{~g} / \mathrm{d})$ were greater $(\mathrm{p}<0.05)$ than both GrassCW (142 $\pm 18 \mathrm{~g} / \mathrm{d})$ and HerbCW ewes $(130 \pm 19 \mathrm{~g} / \mathrm{d})$.

In 2016, live weight of ewes at L51 did not differ ( $>0.05)$ (Table 4). Live weight of ewes in HerbCW and GrassCW treatment groups at L82 and L93 did not differ ( $p>0.05)$ but were heavier $(\mathrm{p}<0.05)$ than HerbEW and Restricted-GrassCW ewes. Liveweight gain between L51 and L93 of GrassCW (65 \pm 21 $\mathrm{g} / \mathrm{d})$ and HerbCW $(61 \pm 20 \mathrm{~g} / \mathrm{d})$ ewes did not differ $(\mathrm{p}>0.05)$ but were greater $(p<0.05)$ than those of HerbEW $(-35 \pm 20 \mathrm{~g} / \mathrm{d})$ and Restricted-GrassCW $(-102 \pm 20 \mathrm{~g} / \mathrm{d})$ ewes. In both years, body condition score of ewes in each treatment group did not differ $(\mathrm{p}>0.05)$ (Table 5).

\section{DISCUSSION}

This study aimed to identify the impact of early weaning of lambs approximately 51 to 58 days after the midpoint of lambing using a herb-clover mix. Early weaned ewes were managed with unweaned ewes and lambs in grass-clover mix until conventional weaning age (in 2015 on unrestricted grass-clover pasture and in 2016 on restricted-grass-clover pasture). In the New Zealand system during late spring to early summer it is unlikely farmers would choose to graze weaned ewes on a high value herbage as a mechanism for them to gain body condition. In contrast lambs are given the priority to achieve high liveweight gains to allow for an earlier slaughter date. Therefore, in this study early weaned lambs were managed with unweaned ewes and lambs on herb-clover mix in both years.

In 2015, when both herbages allowed for unrestricted allowance $(>1,200 \mathrm{~kg} \mathrm{DM} / \mathrm{ha})$ early weaning onto herb-clover mix resulted slower growth rates of lambs compared to those

Table 5. Effect of weaning treatment on body condition score of ewes (Results displayed as mean with 95\% confidence interval)

\begin{tabular}{|c|c|c|c|c|c|c|}
\hline Weaning treatment ${ }^{1)}$ & $n$ & Body condition score & $\mathrm{n}$ & Body condition score & $\mathrm{n}$ & Body condition score \\
\hline 2015 & & L58 & & L81 & & L95 \\
\hline HerbEW ${ }^{A}$ & 22 & $2.5(1.9-3.2)$ & 21 & $2.9(2.3-3.8)$ & 22 & $2.9(2.3-3.7)$ \\
\hline GrassCW ${ }^{c}$ & 22 & $2.6(2.0-3.3)$ & 22 & $2.8(2.2-3.6)$ & 22 & $2.7(2.1-3.5)$ \\
\hline 2016 & & L51 & & L82 & & L93 \\
\hline HerbEW ${ }^{D}$ & 22 & $3.0(2.4-3.8)$ & 22 & $2.9(2.3-3.7)$ & 21 & $3.0(2.4-3.8)$ \\
\hline Restricted-Grass $\mathrm{CW}^{G}$ & 20 & $2.7(2.0-3.5)$ & 20 & $2.6(1.9-3.4)$ & 20 & $2.5(1.9-3.3)$ \\
\hline
\end{tabular}

SEM, standard error of the mean; L, days after the midpoint of lambing; HerbEW, early weaning onto unrestricted allowance of herb-clover mix; HerbCW, lambs+dams offered an unrestricted allowance of herb-clover mix until conventional weaning; GrassCW, lambs+dams offered unrestricted allowance of grass-clover pasture until conventional weaning; Restricted-GrassCW, lambs+dams offered with restricted allowance of grass-clover pasture until conventional weaning.

${ }^{11} A$ ewes grazed with $C$ lambs and their ewes in 2015. B and $E$ ewes grazed with their lambs in B and $E$, respectively. $C$ ewes grazed with $C$ lambs and A ewes in 2015. In 2016, D ewes grazed with $G$ ewes and their lambs. F ewes grazed with their lambs in $F$. $G$ ewes grazed with their lambs in $G$ and D ewes. 
weaned at a conventional age on the herb-clover mix and grass-clover pasture. However, pasture supply is often restricted during late spring and early summer in New Zealand $[12,13]$, therefore, in 2016 an additional weaning treatment; restricted allowance of grass-clover pasture $(<1,200 \mathrm{~kg} \mathrm{DM} / \mathrm{ha})$ was added to simulate this scenario. In 2016, lambs weaned early onto the herb-clover mix had greater liveweight gains than lambs left with their lambs on restricted grass-clover pasture. Restricted pasture availability during late lactation is known to have negative impacts on milk yield [20], length of lactation [21], and lamb liveweight gain [22]. Therefore, early weaning onto alternative forages such as a herb-clover mix can be a useful management tool if the availability of grass-clover pasture is likely to result in the ewe and lamb becoming competitors [11] resulting in restricted intake. It is important to note that in both years, growth of early weaned lambs on unrestricted allowance of pasture to conventional weaning was greater than $240 \mathrm{~g} / \mathrm{d}$. Therefore, even in years in which pasture availability was not limiting early weaning onto a herb-clover mix can be utilised to achieve acceptable lamb growth rates. The slower growth of early weaned lambs onto herb-clover mix compared to lambs kept with their dams on herb-clover mix until conventional weaning is likely explained by lack of milk intake and the lamb's inability to compensate for this. It is also reported that ewes grazing a herb-clover mix showed an increased milk production [8].

The current study design also allowed for a comparison of the growth of lambs weaned conventionally on unrestricted herb-clover and grass-clover pasture. Previous studies have shown that lambs on a herb-clover mix have heavier weights than lambs on grass-clover mix at conventional weaning [8]. In this study, there was no difference in weaning weights of lambs at conventional weaning in 2015 but in 2016 lambs on herb-clover mix were heavier than on grass-clover pasture. A potential explanation for this could be herbage quality and composition between years. In general, studies that have reported greater growth of lambs post weaning onto herb-clover mix, the ME of herb-clover mix was clearly greater than that of the grass-clover pasture $[1,23]$. However, in this study, the ME of herb-clover mix and grass-clover pasture did not differ always and when they did, the differences were small. The clover content of grass-clover pasture was higher in 2015 than in 2016. While in 2016 the grass-clover pasture had some dead plant matter that was not present in 2015 and only $1 \%$ clover. Lambs are known to selectively graze higher ME plant components (white clover) amongst a grass-clover pasture [24,25], and achieve greater liveweight gains when grazed as a pure clover sward [26]. Given lower clover content in grass-clover pasture in 2016 than in 2015, it would have been difficult for lambs to select white clover, which has higher digestibility and $\mathrm{ME}$, and gain live weights in 2016. Combined these compositional changes could help explain why there was no difference of lamb growth in 2015 in herb-clover mix and grass-clover pasture but there was in 2016.

Early weaning of lambs was advantageous for the ewe in 2015 but this was not found to be the case in 2016. The difference of ewe liveweight between years was likely due to the feed offered to ewes post weaning in each year. In 2015, weaned ewes were offered unrestricted grass-clover pasture while in 2016 they were offered restricted grass-clover pasture post weaning. Nonetheless, no differences in ewe body condition score were observed in both years. Combined these results suggest that early weaning can be used as a tool to increase ewe liveweight gain if subsequently the ewes are offered unrestricted pasture conditions. However, the loss of live weight per day on the restricted conditions in 2016 was not as large as the live weight per day of unweaned ewes under same feeding conditions. This is likely due to the removal of lactational nutritional requirement from weaned ewes. This indicates that under conditions where the grass-clover pasture supply is restricted early weaning can still be advantageous for the ewe.

\section{CONCLUSION}

The effect of early weaning onto herb-clover mix on lamb liveweight gain was more apparent when pasture conditions were restricted. This suggests that lambs can be weaned early onto herb-clover mix to gain greater live weight under conditions where grass-clover pasture supply is restricted than unrestricted. Early weaning of lambs onto herb-clover mix can also have positive effect on ewe liveweight gain particularly under unrestricted supply of grass-clover pasture conditions. Combined these results indicate that the lambs most likely to benefit from early weaning onto a herb-clover mix are those that are grazing with their dams on restricted grass-clover pastures.

\section{CONFLICT OF INTEREST}

We certify that there is no conflict of interest with any financial organization regarding the material discussed in the manuscript.

\section{ACKNOWLEDGMENTS}

The authors thank Beef + Lamb New Zealand for the financial support, and Tuapaka farm staff for technical assistance. The main author was also funded by Massey University Doctoral Scholarship.

\section{REFERENCES}

1. Somasiri SC. Effect of herb-clover mixes on weaned lamb growth [PhD Thesis]. Wellington New Zealand: Massey Uni- 
versity; 2014.

2. Navarrete S, Kemp PD, Back P, Pain SJ, Lee JM. Effect of grazing frequency by dairy cows on herb based pastures. In: Michalk DL, Millar GD, Badgerty WB, Broadfoot KM, editors. Proceedings XXII International Grassland Congress. Sydney, Australia; 2013. pp. 1173-4.

3. Cranston LM, Kenyon PR, Morris ST, Kemp PD. A review of the use of chicory, plantain, red clover and white clover in a sward mix for increased sheep and beef production. J NZ Grassl 2015;77:89-94.

4. Somasiri SC, Kenyon PR, Kemp PD, Morel PCH, Morris ST. Herb-clover mixes increase lamb live weight gains and carcass weight in the autumn period. NZ J Agric Res 2015;58:384-96.

5. Somasiri SC, Kenyon PR, Kemp PD, Morel PCH, Morris ST. Effect of herb-clover mixes of plantain and chicory on yearling lamb production in the early spring period. Anim Prod Sci 2018;56:1662-8.

6. Kenyon PR, Kemp PD, Stafford KJ, West DM, Morris ST. Can a herb and white clover mix improve the performance of multiple bearing ewes and their lambs to weaning? Anim Prod Sci 2010;50:513-21.

7. Golding KP, Kemp PD, Kenyon PR, Morris ST. High weaned lamb live weight gains on herbs. Agron NZ 2008;38:33-9.

8. Hutton PG, Kenyon PR, Bedi MK et al. A herb and legume sward mix increased ewe milk production and ewe and lamb live weight gain to weaning compared to a ryegrass dominant sward. Anim Feed Sci Technol 2011;164:1-7.

9. Corner-Thomas RA, Kemp PD, Morris ST, Kenyon PR. Grazing alternative herbages in lactation increases the liveweight of both ewe lambs and their progeny at weaning. Anim Prod Sci 2014;54:1741-6.

10. Geenty K. Lactation and lamb growth. In: Cottle D, editors. International Sheep and Wool Handbook. Nottingham, UK: University Press; 2010. p. 259-76.

11. Kenyon PR, Webby RW. Pastures and supplements in sheep production systems. In: Rattray PV, Brookes IM, Nicol AM, editors. Pasture and supplements for grazing animals. Hamilton, New Zealand: NZ Soc Anim Prod; 2007. p. 255-74.

12. Baars A, Radcliffe JE, Mike JR. Climate change effects on seasonal patterns of pasture production in New Zealand. Proc NZ Grassl Assoc 1990;51:43-6.

13. Coop IE. Matching feed supply and demand. In: Mccutcheon,
Mcdonald MF, Wickham GA, editors. Feeding, growth and health. NZ Ins Agric Sci., Auckland, New Zealand: Ray Richards Publishers; 1986. p. 137-62.

14. Morris ST, Kenyon PR. The effect of litter size and sward height on ewe and lamb performance. NZ J Agric Res 2004;47:27586.

15. Nowak R, Poindron P. From birth to colostrum: early steps leading to lamb survival. Reprod Nutr Dev 2006;46:431-46.

16. Frame J. Herbage mass. In: Hodgson J, Baker R, Davies DA, Laidlaw AS, Leaver J, editors. Sward measurement handbook. Cheshire UK: British Grassland Society; 1993. p. 39-69.

17. Roughan P, Holland R. Predicting in-vivo digestibility of herbages by exhaustive enzymic hydrolysis of cell walls. J Sci Food Agric 1977;28:1057-64.

18. AOAC. Official methods of analysis of the AOAC International. 18th edn. Gaithersberg, MD, USA: AOAC International; 2007.

19. Robertson J, Van Soest P. The detergent system of analysis and its application to human foods. In: James WPT, Theander O, editors. The analysis of dietary fiber in food. New York, NY, USA: Marcel Dekker Inc; 1981. p. 123-58.

20. Peart JN. The influence of live weight and body condition on the subsequent milk production of Blackface ewes following a period of undernourishment in early lactation. J Agric Sci 1970;75:459-69.

21. Cannas A. Feeding of lactating ewes. In: Pulina G, Bencini R, editors. Dairy sheep nutrition. Wallingford, UK: CAB International; 2004. p. 151-64.

22. Muir PD, Smith NB, Wallace GJ, Fugle CJ, Bown MD. Maximizing lamb growth rates. Proc NZ Grassl Assoc 2000;62:558.

23. Golding KP, Wilson ED, Kemp PD, et al. Mixed herb and legume pasture improves the growth of lambs post-weaning. Anim Prod Sci 2011;51:717-23.

24. Pain SJ, Hutton PG, Kenyon PR, Morris ST, Kemp PD. Preference of lambs for novel pasture herbs. Proc NZ Soc Anim Prod 2010;70:285-7.

25. Rutter SM. Diet preference for grass and legumes in free-ranging domestic sheep and cattle: current theory and future application. Appl Anim Behav Sci 2006;97:17-35.

26. Fraser TS, Rowarth JS. Legumes, herbs or grass for lamb growth? Proc NZ Grassl Assoc 1996;58:49-52. 